\title{
Social work as revolutionary praxis? The contribution to critical practice of Cornelius Castoriadis's political philosophy
}

Ablett, Phillip; Morley, Christine

https://research.usc.edu.au/discovery/delivery/61USC_INST:ResearchRepository/12126768270002621 ?\#13133818770002621

Ablett, P., \& Morley, C. (2019). Social work as revolutionary praxis? The contribution to critical practice of Cornelius Castoriadis's political philosophy. Critical and Radical Social Work, 7(3), 333-348.

https://doi.org/10.1332/204986019X15695800764884

Link to Published Version: https://dx.doi.org/10.1332/204986019X15695800764884

USC Research Bank: https://research.usc.edu.au

research-repository@usc.edu.au

It's your responsibility to determine if additional rights or permissions are needed for your use.

Downloaded On 2020/11/25 07:16:28 


\title{
The Contribution to Critical Practice of Cornelius
}

Castoriadis's Political Philosophy

\author{
Phillip Ablett, University of the Sunshine Coast
}

Christine Morley, Queensland University of Technology

\begin{abstract}
Social work is a contested tradition, torn between the demands of social governance and autonomy. Today, this struggle is reflected in the division between the dominant, neoliberal agenda of service provision and the resistance offered by various critical perspectives employed by disparate groups of practitioners serving diverse communities. Critical social work challenges oppressive conditions and discourses, in addition to addressing their consequences in individuals' lives. However, very few recent critical theorists informing critical social work have advocated revolution. A challenging exception can be found in the work of Cornelius Castoriadis (1922-97), whose explication of ontological underdetermination and creation evades the pitfalls of both structural determinism and poststructural relativism, enabling an understanding of society as the contested creation of collective imaginaries in action and a politics of radical transformation. On this basis, we argue that Castoriadis's radicaldemocratic revisioning of revolutionary praxis can help in reimagining critical social work's emancipatory potential.
\end{abstract}

\section{Key Words}

critical social work, Castoriadis, revolution, ontology, autonomy

\footnotetext{
This is the author's pre-print version of the work that was submitted/ accepted for publication as: Ablett, Phillip \& Morley, Christine (2019) 'Social Work as Revolutionary Praxis? The Contribution to Critical Practice of Cornelius Castoriadis's Political Philosophy'. Critical and Radical Social Work. 7(3), pp. 333-348. @ Policy Press. DOI: https://doi.org/10.1332/204986019X15695800764884
} 


\section{Introduction}

Social work has always been a contested tradition - torn between the competing demands of social governance and autonomy. Today, this struggle is reflected in the division between the dominant, neoliberal disciplining of service provision and the resistance offered by various critical perspectives employed by disparate groups of practitioners serving diverse communities. The latter 'critical social work' tradition seeks to transform oppressive conditions and discourses, in addition to addressing their consequences in individuals' lives. However, very few recent critical theorists (whether Marxian, feminist or post-structural) drawn upon by critical social work have articulated a revolutionary critique for the transformation of neoliberal capitalism and associated forms of oppression. A challenging exception can be found in the work of the post-Marxist philosopher Cornelius Castoriadis (1922-97), whose theory of society as the contested creation of collective imaginaries in action remains largely untapped by social workers concerned with the theory and practice of radical social change.

While the engagement with Castoriadis's ideas in social work is negligible, exceptions exist in Shuttleworth's $(1992 ; 2013)$ work on aged care and disabilities, rethinking autonomy in relation to heteronormativity, ableism, medicalisation and ageism. There is also insightful reference to Castoriadis by Madhu (2005) around the notion of 
'praxis' but not Castoriadis's central thematic of revolutionary praxis.

This article seeks to augment the development of critical social work by explicating aspects of Castoriadis's work that may yield fresh perspectives on abiding theoretical and political tensions in emancipatory practice, most notably, in attempts to combine the concerns of poststructuralism with critical theory for radical change (Pease et al, 2016). Unlike the mainstream social theorists drawn upon by many social workers (for example, Giddens, Beck, Bourdieu or Habermas), Castoriadis's project refuses the confines of parliamentarism within a capitalist state and economy. In this, it shares major affinities with Marxian thinkers like Negri, Badiou and Ranciere, whose ideas are being utilised in the renewal of social work's 'New Left' (Gray and Webb, 2009; 2013; Garrett, 2015; 2018). Indeed, we argue that Castoriadis's work provides a coherent and robust revisioning of revolutionary praxis that can help clarify and extend the revisioning of critical social work's emancipatory potential without recourse to deterministic structural theories or the pitfalls of post-structural relativism.

Our discussion commences with a sketch of Castoriadis's life and work. Castoriadis was no armchair theoretician, but rather, in the manner of Marx, Addams, Gramsci, Fanon and Freire, an activist-intellectual concerned with rethinking the ways in which the imagination, theory and practice might promote human freedom and justice (Castoriadis, 1987). In this view, theory is not a mirror of reality or master guide to action, but 
rather a moment of lucid critical reflection within the processes of social change that can help effect a difference. As Castoriadis (1987: 57) explains: 'We are not in the world to look at it or submit to it; our fate is not servitude; there is a type of action that can be based on what is, in order to bring into existence what we want to be.'

Accordingly, the discussion proceeds by showing how Castoriadis's writing addresses three major concerns of critical social work, namely: (1) the philosophical basis of knowledge, which is currently characterised by debates between various realist positions (for example, the privileging of 'evidence-based practice') and constructionism; (2) the substantive analysis of society and the individual; and (3) the question of emancipatory praxis. Addressing these concerns, the exposition highlights Castoriadis's concepts of ontological underdetermination and creation, which underpin his theory of society as the contested institution of a 'magma' of imaginary significations and so provides grounds for the radically democratic revolutionary project of autonomy (Castoriadis, $1987 ; 1990 \mathrm{~b})$.We should add that this is a project that challenges not only neoliberal capitalism, but also multiple, forms of oppression, including racism, patriarchy, ableism, fundamentalism, heteronormativity and environmental despoliation, on which Castoriadis either wrote directly or to which his work has been extended by others. However, due to limited space, we have focused primarily on his critique of capitalism in presenting his revolutionary project. 


\section{A Revolutionary Life}

Castoriadis was born in 1922 in Constantinople (Istanbul) to a Greek family who migrated to Athens in the wake of the Greco-Turkish War and its subsequent 'ethnic cleansing'. By age 13, he began reading Marx, which became a politicising activity under the Metaxas dictatorship (Memos, 2014). In 1937, Castoriadis joined the Athenian Communist Youth, and in 1941, he joined the Greek Communist Party (KKE), which waged an armed struggle against the Nazi occupation. He also attended the University of Athens, graduating in politics, economics and law (Curtis, 1992). As a student, despite political differences, Castoriadis saw value in Max Weber's work on bureaucracy and his emphasis on collectively shared meanings in constructing social forms (Castoriadis, 1990a). A relentless questioner of received ideas, Castoriadis saw that all philosophical systems produced contradictions - 'aporias and impasses' (Castoriadis, 1997b: 371) - that could not be resolved within the system. In politics, this same critical spirit led him to break with Soviet communism when, in 1942, he joined the Trotskyists, effectively placing him on the death lists of both fascists and Stalinists for the duration of the war (Peregalli, 2002).

In 1945, Castoriadis won a scholarship to study at the Sorbonne in Paris (Castoriadis, 1997b), where he took work as an economist at the headquarters of the Organisation for Economic Co-operation and 
Development (OECD). He also joined the Trotskyist Fourth

Internationale, which was debating the nature of socialism. Against the majority, Castoriadis argued that existing Soviet regimes were not socialist, but (combining Marx and Weber) 'bureaucratic capitalist' states with a new 'ruling class', and that another revolution would be necessary before socialism was possible. In 1948, Castoriadis broke with Trotskyism and the idea of a vanguard party to form (with Claude Lefort) a new libertarian-socialist organisation, Socialisme ou Barbarie (Socialism or Barbarism; henceforth S. ou B.) with a journal of the same name (Castoriadis, 1997b).

An economist in his 'day job' (and non-citizen vulnerable to deportation at 24 hours' notice), Castoriadis lived a revolutionary's double life for the next two decades, agitating under the noms de plume Pierre Chaulieu, Paul Cardan and Jean-Marc Coudray (Singer, 1979). S. ou B. had a number of organisers in several factories (notably, at Renault) and prominent intellectuals who developed original analyses of their own, like Guy Debord of the Situationists, the complexity thinker Edgar Morin and the postmodernist Jean-François Lyotard (Hastings-King, 1999).A decade before the emergence of the New Left, S. ou B. supported anti-colonial struggles in Africa, welcomed African-American militancy in the US, opposed the industrial drive to 'conquer nature' and organised women's consciousness-raising meetings to establish 'new relations between the sexes' (James et al, 2005 [1958]). 
As S. ou B.'s chief theoretician (1949-66), Castoriadis initiated a series of unsparing critiques of orthodox Marxism, extending his thesis on bureaucratic capitalism. He argued that the central dynamic of capitalism had shifted from ownership to a basic power division in society (East and West) between 'order-givers' (executives) and 'order-takers' (exécutants) in both production and civic life (Castoriadis, 1987). This division resulted in both political and economic struggles. The thesis found validation in workers' uprisings in the Soviet bloc (East Germany in 1953; Hungary in 1956) and post-war 'wildcat' strikes in the US. Accordingly, Castoriadis rejected statist definitions of socialism from above (via nationalisation and centralised planning), advocating instead 'socialism from below' via workers' self-management (autogestion), which he would expand into the radically democratic project of human autonomy. The theory also emphasised multiple forms of social oppression and division (beyond Marxist class analysis), whose overcoming would require collective action. By the time S. ou B. broke up in 1966, Castoriadis declared having 'arrived at the point where we have to choose between remaining Marxist and remaining revolutionaries, between faithfulness to a doctrine ... and faithfulness to the project of a radical change of society' (Castoriadis, 1987: 14). However, unlike many 'post-Marxist' contemporaries, Castoriadis's reclamation of the revolutionary project makes no concessions to capitalism (Ojeili, 2001). 
The ideas of self-management, autonomous collective action and new democratic forms transcending capitalism articulated in the pages of S. ou B. found unexpected vindication in the Parisian student-worker uprising of May 1968. Its most prominent leader, Daniel Cohn-Bendit (CohnBendit and Cohn-Bendit, 1968), attributed many of his ideas to 'plagiarising' Castoriadis, who worked clandestinely throughout the revolt. Despite its failure, the uprising confirmed Castoriadis's impression that 'spontaneous' mass actions and the creation of new, participatory forms remain possible, even if their success can never be guaranteed. For social work, such insights offer new opportunities to conceptualise the nature and politics of a profession formally committed to liberation and justice (IFSW, 2014) in far more radical terms than current mainstream practice would envisage.

In 1970, Castoriadis obtained French citizenship, retired from the OECD and retrained in psychotherapy under Jacques Lacan, but broke with the latter's structuralism, commencing practice in 1974 (Curtis, 1992). This shift saw Castoriadis linking his concerns for both personal and social autonomy more explicitly. He continued developing his political and philosophical ideas during the last three decades of his life as director of studies at the Écoles des Hautes Etudes. He also engaged with various movements for expanding the direct democracy of citizens in transforming neoliberal capitalist society, including the 'European Green parties' and the participatory budgeting movement initiated by the 
Brazilian Workers Party at Porto Alegre (Souza, 2000). In December 1997, Castoriadis died after heart surgery in Paris at age 75 (Agora International, 2014).

The critical legacy of Castoriadis is consolidated in his most famous text, The Imaginary Institution of Society (Castoriadis,1987), in the first section of which he explicitly reformulates the revolutionary project. In subsequent essays, there are many parallels with the writings of critical theorists, and he shares some concerns with postmodern/post-structural thinkers in the critique of foundationalism. However, Castoriadis (1992) repudiates postmodernism as 'the French Ideology' (recalling Marx's break with The German ideology) due to its epistemic relativism (Breckman, 1998) and his explicitly emancipatory, praxis-oriented agenda. His work therefore holds significant implications for critical social work in which tensions between post-structuralism and critical theory persist.

\section{Critical Social Work}

Critical approaches to social work are broad, diverse and contested.

While some critical social workers (influenced by Marxism or Marxian critical theory) place more emphasis on the ubiquity of societal structures like capitalism wreaking havoc on people's lives (Moreau 1979; Mullaly 2007; Ferguson and Lavalette, 1999; Ferguson 2008; Lavalette, 2011), others influenced by postmodernism point to 
the irreducibility of multiple truths experienced by diverse identities subject to varying forms of oppression and exclusion (Leonard, 1997; Parton and O'Byrne, 2000), and still others attempt to work through the tensions between these positions (Pease and Fook, 1999; Allan et al, 2009; Morley and Macfarlane, 2012; Pease et al, 2016; Morley et al, 2019).

Key features of critical social work include: a critical analysis of the ways in which socio-political structures create inequality and are therefore implicated in producing personally experienced problems; a critical analysis of language and power, and the interplay between these; a resistance to harmful social forces that create social divisions and oppression; the questioning of taken-for-granted assumptions; the capacity for critical self-reflection; a valuing of a wide range of knowledges; the promotion of respectful relationships; the decolonisation of social work to embed indigenous ways of knowing and practising; and activism for a more just, participatory and sustainable world (Morley et al, 2019). This position is currently under assault from many quarters: material inequalities are increasing; xenophobic and authoritarian populism is undermining democratic governance; eco-crisis is threatening the future of humanity; and service provision for the victims of the crises is being reduced to austere managerial techniques. Critical social work, with few exceptions (Ferguson, 2008; Lavalette, 2011; Gray andWebb, 2013; 
Garrett, 2015), has faced this crisis context with a largely reformist and not a revolutionary agenda. Therefore, a consideration of Castoriadis's work offers critical social workers timely philosophical and political insights into the meaning and possibilities of revolution today.

\section{Ontological Underdetermination and Creation: Leaving}

\section{Space for Revolution}

Castoriadis's critique of Western philosophy questions not only its theories of knowledge (epistemology), but also its prevailing understanding of being (ontology) since Plato. This has direct implications for social work as, until relatively recently, ontology has been neglected in favour of epistemology in social work academic literature (Aymer and Okitikpi, 2000; Borden, 2010; Bell, 2012). However, in reviewing social work research paradigms, as ArndCaddigan and Pozzuto (2006: 424) point out, 'Notions of epistemology ... [always] rest within an ontology' because ontological questions ask: 'what is the nature of the world one wishes to know about?'. Consequently, major philosophical debates in social work between realism and social constructionism are as much ontological as they are epistemological. In realism, for example, being is conceived as independent of the researcher/practitioner, albeit knowable via analytical-empirical methods. In constructionism, by contrast, being is something constituted intersubjectively and contingently by language 
and culture. Beyond this sparse binary, Arnd-Caddigan and Pozzuto (2006: 435) say that all further statements about the nature of being are speculative, leaving the realist-constructionist binary entrenched. Castoriadis's ontology, by contrast, decentres this binary and offers an alternative standpoint.

According to Castoriadis (1987: 41), the dominant ontology of Western thought is 'objectivist rationalism', or what he later calls an 'ensemblist-identitarian'(Castoriadis, 1987: 177) logic, which treats the universe (natural and social) as an exhaustive set of discretely identifiable forms (material and ideal) that are related through deterministic chains of inevitable cause and effect. Therefore, the 'truth' of any phenomenon is exhausted once the mechanism of its causality or functionality within a preceding sequence is identified. This ontology gives rise to the mistaken view that the world can be subject to 'rational mastery', whereby determinate knowledge can be used to prescribe practice with a high degree of certainty regarding the outcome regardless of the circumstances (Castoriadis, 2007: 86). Despite epistemological distinctions, this same deterministic ontology underpins all forms of scientism, positivism, rationalist- empiricism, realism and evidence-based practice.

Over 20 years ago, Peile (1993) and Zimmerman (1989) drew on cosmology to expose the problematic dominance of determinism in 
social work theory and practice. Today, ontological determinism in social work is most evident in the movement for 'evidence-based practice', where, as Madhu (2005: 267) says:

[The] underlying assumption is that there exist permanent and empirically observable regularities between the problems faced by the client and the specific intervention.... Once the relationship is found, all that is necessary is to develop a 'package' of social work practice that could be administered with the systems of management meant for that.... In this approach, the social problem and its manifestations are treated as if the society is an object.

In the light of Castoriadis's theory, the problem with this sort of approach is not that its findings are invalid, but rather that it privileges the determinate elements of the universe as exhaustive, and therefore distorts them. However, unlike extreme relativist versions of postmodernism (for example, Lyotard, 1993), Castoriadis (1987) does not view the 'real' (empirically testable) and 'rational' (logically deducible) aspects of being as simply a function of language without any contribution from the nonlinguistic world. Determinate relations are demonstrable (for example, that water boils at $100{ }^{\circ} \mathrm{C}$ at sea level and capitalist income inequalities increase without redistributive regulation) and cannot be arbitrarily dissolved. However, he insists these relations are but fragments and can never provide a definitive account of their subject matter. Relations of cause and effect reveal just one determinate layer of being. However, 
there remains a vast indeterminate layer that cannot be apprehended in this way but must be considered in understanding the human world and our actions within it. Castoriadis (1984) cites Heisenberg's 'uncertainty principle' in quantum physics and Godel's 'incompleteness theorem' in mathematics as evidence for indeterminacy in the physical universe. This underdetermined quality becomes even more apparent when attempting to explain the social world in rational-empirical terms (that is, the social sciences), where we are only 'able to find a theory of partial "objective dynamics"' (Castoriadis, 1987: 43-4), with no prospect of integrating these pieces into a system. In Castoriadis's view, those aspects of the social world subject to causal explanation are exceptional, representing just a few 'islands of determinacy in an ocean of indeterminacy' (Joas, 1989: 1192).The determinate elements we encounter in empirical studies are constantly interpenetrated by the indeterminate elements, rendering any scientific account of social problems or their solution partial, incomplete and fragmentary.

Castoriadis sees ontological indeterminacy not as a political liability, but rather as a hopeful ground for those committed to revolutionary change. If society (and the individual) were entirely determinate, then it would be impossible to even conceive of genuinely new acts of creation or new ways of being. Freedom (self-determination and self-conscious agency) would itself be illusory, being the function of some other set of determinate processes or structures. All social change would consist in the 
determinable and predictable rearrangement of elements within a pregiven set (for example, historical laws, linguistic structures, genetic codes and so on) but not the creation (ex nihilo) of something new. However, Castoriadis insists that we are constantly creating new images, forms and meanings. For example, at some point in history, somebody, somewhere invented the wheel as something utterly new, as something that never existed before and could not have been deduced from any set of preexisting elements. The source of this underdetermined creativity in the social world for Castoriadis is the human imagination, both at the personal (radical imaginary) and collective (social imaginary) level (Castoriadis, 1987).

The imaginary, in Castoriadis's (1997a: 84) sense, is not merely the illusory, but rather the capacity of human beings (whether conscious or not) for 'positing new forms'. Imagination enables us 'to see in a thing that which is not or not yet' (Castoriadis, 1987: 104). For Castoriadis (1987: 150), the social imaginary includes the constantly unfolding constellations of instituted social meanings 'that value or devalue, structure and hierarchize, an intersecting ensemble of objects and corresponding lacks', that justifies the world view and practices of a social grouping. This includes a range of tacit knowledge, evaluative standards, aesthetic criteria, habits of thought and notions of 'what is' and 'what ought to be' with which people operate in and change society. The creations of the imagination, whether individual or social, are never solely 
determinate. History admits the possibility of people doing things otherwise than predicted, to "provide new responses to the "same" situations or create new situations' (Castoriadis, 1987: 44, emphasis in original). Consequently, for Castoriadis (in Joas, 1989: 1191), 'there can be no [causal] "explanation" of a creation; there can only be a comprehension ex post facto of its meaning'. While we can attempt the elucidation of the social world and its problems (constantly explicating their determinate and indeterminate aspects), we never achieve the rational closure or control that evidence- based social work assumes, which Castoriadis would deem epistemologically and politically naive.

In the absence of such ontological critique, the proponents of evidencebased social work typically and uncritically situate their empirical findings within the dominant social imaginary, currently characterised by the marriage of rationalist objectivism with neoliberal managerialism (Webb, 2001: 78). This framing conceals its own constructed and imaginary character (including its ethical, ideological and political nature) by focusing solely on narrow, technical, performance-oriented criteria that foster the delusion of 'rational' mastery (Castoriadis, 1997a: 37). By contrast, the recognition of ontological underdetermination and the creative imaginary basis of human understanding could potentially relieve social workers from the impossible goal of omniscient expertise in managing social problems. Simultaneously, it encourages critical social workers' creative freedom to entertain and question multiple sources of 
understanding and to re-situate research findings in the service of alternative, emancipatory imaginaries (Bryant, 2015; Strega and Brown, 2015). Such understanding would always have a provisional, anticipatory and reflexive character without the pretentions of deterministic objectivism. However, emancipatory imaginaries are not ready-made or static; they have to be created and recreated in collaboration with others: practitioners, the people they work with, citizens and non-citizens. To assist this, Castoriadis (1987) provides theoretical tools that might help social work in exposing social injustices and oppression with a view to radical transformation.

\section{Theory of Society and the Individual}

Critical social work's understanding of social change faces the same conceptual dilemmas confronting critical theory generally, including the relation of the social to the non-social, the relation of inherited social forms (structure) to agency, and the relation between the individual and society. Castoriadis's ontology of underdetermined creativity reframes these concerns.

As indicated earlier, Castoriadis $(1987: 234,250)$ characterises the 'social' domain as the ongoing creation in action of collective imaginary significations. Social action 'leans on' but is not reducible to any physical, biological or psychological 'substratum'. These things may condition, but they never determine, the social or (as Castoriadis prefers) 
the socio-historical domain, which has its own dynamism in the social imaginary.

Consistent with his ontology, Castoriadis's social theory centres on social action rather than social structures. In this, he opposes theories that replace the contested ebb and flow of meaningful social practices by privileging the classification and analysis of underlying forms (Metcalfe, 1989). Prominent examples that tend towards this form of theorising are found in functionalism, structuralism, systems theory, most Marxisms and early 'structural' social work. Despite the latter two's emancipatory aims, the objectified abstractions of such perspectives can engender a structural determinism that obscures the actions of human beings in making society. A similar critique of structural social work's implicit determinism and how this can contribute to a sense of powerlessness and pessimism regarding the prospects for social change has been staged by a number of critical social work scholars (Healy, 2000; Leonard, 1997; Fook, 2016) influenced by postmodernism.

Castoriadis argued for a radical reframing rather than the dissolution of structural concepts, stressing that all 'structural forms', 'systems needs' and 'functions' have to be understood as constituted through the significations (social meanings) provided by a social imaginary, and are therefore always open to historical contestation and alteration (Honneth, 1986: 68; Joas, 1989: 1190). Structures and institutional forms do not 
determine history, but are its transient products. Rather than thinking in terms of structures, Castoriadis refers to the unstable semi-solid, semifluid character of the social world as the 'magma' of social imaginary significations, in which social forms are constantly in the process of emergence and transformation. For Castoriadis, society is an always open-ended dialectic between the created network of symbolically mediated institutions and the creating of new ones: 'the union and the tension of instituting society and of instituted society, of history made and of history in the making' (Castoriadis, 1987: 108, emphasis in original).Therefore, social change occurs not as the outcome of universal laws, but as new ideas and practices erupt within the existing order, and hence 'society as instituted is self-destructed by society as instituting' (Castoriadis, 1987: 201, emphases added).

Reinterpreting and interrogating social 'structures' through Castoriadis's 'magmatic' lens as the contested creations of collective imaginations in action challenges fatalistic constructions of society and individuals. A critical interrogation of the imaginaries that invest dominant institutions and social divisions with their sense of immutability is the first step to their delegitimation and the reclamation of creative power by the dominated. What is exposed in every social division or institution is the constant interplay between the symbolic practices reproducing the 'instituted' order and those 'instituting' something new (Castoriadis, 1987). 
By placing the creative imagination at the centre of his social theory, Castoriadis develops a conception of agency that refuses to oppositionalise society and the individual. Instead, he posits a more fundamental distinction between society (the socio-historical) and the unsocialised psyche (Curtis, 1992: 50). Here, the psyche is understood as the unconscious source of the radical imagination (an elementary flux of images both real and unreal) that, from the moment of birth (perhaps before), is disciplined by the social imaginary through socialisation and cannot survive without it. Hence, the individual is always already a social institution, a fragment - 'or, better a sort of hologram - of the social world' (Castoriadis, 1997a: 2) and its contradictions.

Regardless of whether one accepts Castoriadis's psychoanalytic usage of psyche, positing an indeterminate source of personal creativity counters both deterministic (Althusser, 1971; Skinner, 1971) and linguistically relativist (Barthes, 1977) accounts of the subject. In Castoriadis's view, the social fabrication of subjectivity conditions, but never completely determines, our individuality. There is a creative part of us that does not simply mirror external reality, but conjures new images and potentially enables us to distinguish and choose alternative social imaginaries (Castoriadis, 1987: 149, 300). In this way, Castoriadis preserves a basis for personal agency and autonomy within the socialised individual, which post-structural analyses reduce to a discursive effect (for example, 
Foucault, 1981 [1970]). However, the creative agency that Castoriadis defends is never simply a matter of rational control, but rather results from the interplay of conscious deliberation, discourses and unconsciously evoked imaginings within society and its individuals.

Understanding society as an imaginary creation does not mean that everyone within it is aware of, or participates equally (democratically) in, this creative process. On the contrary, since the rise of 'civilisation' in ancient Mesopotamia, most societies have been characterised by heteronomy (that is, 'rule of the other'), in which the imaginary of the dominant group is instituted as natural, inevitable or divinely sanctioned (Castoriadis, 1987: 155). Castoriadis (1997a: 16-17) defines heteronomy as 'the state where laws, principles, norms, values and meanings are given once and for all and where the society or the individual, as the case may be, has no action upon them'. Heteronomous imaginaries justify disparities in power and wealth, while concealing the socially constructed nature of these divisions. Multiple heteronomous divisions (principally around significations such as the market, state, nation, class, gender, ability, race and so on) intersect all contemporary societies (Castoriadis, 1987: 109). Contemporary capitalism exemplifies a heteronomous social imaginary, whose key significations (of 'markets' and 'commodities') are presented as inevitable forces beyond human making or democratic accountability. These significations order and propel the enormous mobilisation of human creativity for limitless growth and profit, as well 
as the impossible quest to rationally master all creativity through techniques and technologies that threaten the future of both meaningful human labour and the earth itself (Castoriadis, 2007).

In contrast to heteronomous societies, there are exceptional cases where the majority of the members of a society become conscious of its selfinstitution and struggle for a more egalitarian collective agency, such as in Ancient Athenian democracy, early Renaissance communes and modern social movements. However, all of these are only partial approximations of the democratic-egalitarian ideal, with exclusions that need to be overcome (for example, the exclusion of women and slaves in Athens). Autonomy (that is, self-rule or self-determination) is therefore an imaginable possibility for the individual and society but by no means inevitable. It is a choice and a struggle. The creative indeterminacy of the social imaginary is a precondition for but cannot guarantee the autonomyenhancing praxis of revolution.

\section{Revolutionary Praxis as the Project of Autonomy}

For Castoriadis, praxis involves human action whose 'goal' is realised in its own enactment. To clarify, Castoriadis cites the examples of educational, healing and revolutionary practices, where a substantive 'end' is expressed in the 'means' or performance, which is deemed intrinsically valuable. Praxis also involves reflection, which may revise prior knowledge in its course and conduct (Joas, 1989). He contrasts 
praxis with technique, which is valorised in corporate and public management settings, where instrumental means are fixated upon to the detriment of worthy goals. In praxis, human reflection creates projects that are constantly interrogated, revised and extended in the light of experience. Castoriadis says that praxis is a conscious, lucid activity and not simply the application of existing knowledge:

It is based on knowledge, but this knowledge is always fragmentary and provisional. It is fragmentary because there can be no exhaustive theory of humanity and of history; it is provisional because praxis itself constantly gives rise to new knowledge.... This is why the relations of praxis to theory ... [are] more profound than those of any 'strictly rational' technique or practice; for the latter, theory is only a code of lifeless prescriptions which can never, in its manipulations, encounter meaning. (Castoriadis, 1987: 76)

For Castoriadis, the reflection involved in genuine praxis can never be simply analytical-empirical, but is essentially creative and critical. Praxis questions 'what' is being done in this or that practice, programme or policy, and 'for what' purpose (Castoriadis, 1984: 235). It is not simply the 'know-how' of technique. In the case of revolutionary praxis, an entire society questions its own constructed nature in a radically democratic fashion, confronting its current problems and injustices with imaginative projections of possible futures. However, if technical knowledge is treated as exhaustive and privileged over the purposeful, participatory and deliberative nature of praxis, then power will accrue to 
'experts', and praxis rapidly degenerates into managerial techniques, which abound in heteronomous welfare regimes. Unfortunately, argues Castoriadis (1987), this degeneration of praxis into technique also characterised Marxism-Leninism, the dominant theory of socialist revolution in the 20th century, reducing history-making to a natural process whose 'laws of motion' it claimed to grasp and know in advance. This equation of theory with deterministic science led to a prescriptive bureaucratisation of politics to effect control (Castoriadis, 1987: 70).Technique has its place in human affairs in limited functional domains (for example, mechanics, accounting, surgery and so on), but when this monopolises the social imaginary, it is the antithesis of revolutionary praxis.

\section{Revolution}

As noted, revolution is not a common theme in social work, even in its more critical- political expressions (Pritchard andTaylor,1979). In actual revolutionary situations, with some notable exceptions, the social work profession has often been identified with the existing regime rather than the oppressed (Nguyen, 2002; Yu, 2006).As Ferguson (2013: 195) affirms: 'There are very few parts of the world in which the activities of social workers can be seen as constituting a threat to the established ... order.' Nevertheless, Ferguson (2016: 90), among others, has also identified a 'new social work radicalism' in the militant participation of organised groups of social workers, starting with the 
Social Work Action Network (SWAN) in the UK, the New Approach

Group in Hungary, the Progressive Welfare Network in Hong Kong and Orange Tide in Spain, assailing the deprivations of neoliberalism.

However, establishing synergisms between social work and revolution necessitates a significant redefinition of the dominant understandings of each project, and Castoriadis's reframing of revolution can be helpful here.

For Castoriadis (1990b: 130), revolution is not defined by 'barricades, violence, bloodshed, and so on', or by seizing the means of production or state power. Rather, the 'socialist revolution aims at transforming society through the autonomous action of people and at establishing a society organized to promote the autonomy of all its members' (Castoriadis, 1987: 95). It is 'the explicit self-institution of society by collective, lucid, democratic activity' (Castoriadis, 1990b: 128). However, 'every time a strong social movement has wanted to transform society radically but peacefully, it has run up against the violence of the established power' (Castoriadis 1990b: 131). So, such movements must be prepared for confrontation by maximising participation in a self-organised fashion, being capable of action but without violating the purpose for which they were instituted. Castoriadis initially identified the general character of modern revolutions with 'socialism', but after 1980, he employs the term 'autonomy' (Castoriadis, 1991). However, the substance of this social vision remained the same: a radically egalitarian, political and economic 
democracy. In contrast to a heteronomous society based on capitalism and representative democracy, an autonomous society facilitates 'people's conscious direction of their own lives' (Castoriadis, 1997b: 51). While Castoriadis focuses on the political nature of autonomy, he emphasises that it would be 'meaningless' without the economic democracy sought by generations of socialists: 'One could not imagine a society where people would be slaves in production every day of the week and then enjoy Sundays of political freedom' (Castoriadis, 1997b: 59).

\section{The Project of Autonomy and Social Work}

'Autonomy' and 'self-determination' are terms that have long been regarded as key aims of social work (Biestick, 1951; McDermott, 1975) but these are largely understood in liberal terms as the (negative) freedom of the individual against the coercive impositions of others or the state. Castoriadis rejects the liberal (and neoliberal) version of an exclusively individual autonomy as lopsided and illusory. An individual is a social creation and cannot therefore be free in an unfree society like capitalism. Autonomy (stemming from the Greek auto ['self'] and nomos ['law']) does not mean atomisation; rather, it means self-governance, both for the individual and society (Castoriadis, 1987: 107). Social autonomy therefore means a society being able to self-consciously institute and revise its own laws with the maximum participation of its members in direct democracy (Castoriadis, 1997a). The project of autonomy begins whenever a 
subordinate group starts to question the dominant imaginary that constructs their subordination as inevitable in order to seek equal participation. Individual autonomy is not fully possible without this collective shift, but, likewise, it begins in critical self-reflection, in bringing one's socially constructed self (and its constructions) into question. Another defining feature of autonomy for Castoriadis (1987: 87 ) is that it must develop 'the autonomy of the other or of others'. This is because only if each person facilitates the autonomy of the other in their society can each expect their own autonomy to be respected. Accordingly, social autonomy must engender a 'selflimiting' regime against majoritarian populism and its tragic consequences. Castoriadis (1997a) anticipates that such self-limiting practices will (must) be supported by an inclusive democratic education or paideía. Beyond this, autonomy is an open-ended project and subject to creative extension (or reversal).

Castoriadis (1991) counterposes this revolutionary project of autonomy, which has only ever been partially approximated in history, to the now-dominant imaginary of neoliberalism, where people surrender their agency to market despotism and 'representative' democracy (which he called 'liberal oligarchy'). Moving from heteronomy to autonomy will require struggles for the direct participation of the public in political and economic life in ways currently discouraged or foreclosed by the instituted imaginary, 
including that of social work. However, the possibility of autonomy as a historical practice (expressed in many social movements) is recurrent in all struggles for inclusive and direct democracy against elite rule. Recent manifestations of direct democratic irruptions are visible in the Icelandic 'pots and pans' revolution, the factory repossession movement in Argentina, the Landless Workers Movement of Brazil, the Rojavan confederation of Syrian Kurdistan, the Zapatistas of Mexico and the continuing reactivation of libertarian socialist tendencies in Spain.

While individuals cannot change society alone, one need not wait for radical movements to emerge before supporting the project of autonomy in public and professional life. Castoriadis (2007: 97) insisted that, historically, 'the seeds of autonomy have already been created and are still alive', even within 'some aspects of ... formal institutions', and the project now 'resides in efforts to preserve and develop those seeds'. Critical social work plays a role in fostering these 'seeds' when it promotes autonomy at every level from casework to social action and policy practice, refusing to delink these domains. We suggest that in casework, analogous to Castoriadis's psychoanalytic practice, there remains the conversational task with individual service users of challenging neoliberal constructions of their alleged 'dysfunction' or failure, identifying contextual constraints, and encouraging the exercise of creative, reflexive and 
relational agency. At the level of social policy and action, the failure of neoliberalism to reduce inequality or poverty is palpable.

Therefore, policies that provide a non-bureaucratic politico-economic floor enabling all people to participate equitably as democratic citizens are paramount for the project of autonomy. Campaigns for an adequate and universal basic income or basic assets, for example, might meet this criterion and are on the agenda in many countries, providing focal points for activism and debate in which social workers are participating (Kennelly, 2017;Ablett et al, 2019). If social workers are to expand their capacity for revolutionary praxis, then social work education must, of course, also prepare them not merely with skills for the existing order, but with a critical paideía of democratic experimentalism for facing the crises and breakthroughs to come (Ablett and Morley, 2020)

\section{Conclusion: Social Work as Revolutionary Praxis?}

This article has engaged with the critical political philosophy of Castoriadis with a view to rethinking the relationship between social work and revolution in a way that interrogates the dominant heteronomous constructions of both projects. This philosophy centres on an ontological standpoint of underdetermined creation, which evades the impasses of determinism and relativism, foreshadowing an emancipatory politics that could enhance the mission of critical social work. 
Castoriadis's critical theory of society as the contested creation of collective imaginaries elucidates a revolutionary praxis without prescriptive, teleological guarantees or an expert vanguard undermining its purpose. Although exceptional, this revolutionary praxis of deliberate and democratic social self-creation, which mutually upholds the autonomy of the other, is repeatedly pursued and emergent in many instances throughout the world. Social workers, committed to socially transformative practices, also participate in such struggles, often in response to the concrete contradictions and suffering in the lives of the people they work with. However, many do so with a conception of social work that still tacitly accepts parliamentarism and a capitalist economy as the last word (Garrett, $2015 ; 2018)$. The project of autonomy articulated by Castoriadis is one of the few that advocates an alternative politics of radical rupture with this heteronomous paradigm, providing an opportunity for social workers to further question and re-envisage the imaginary of their profession and of the society in which it operates. In attesting to the revolutionary power of the imagination, Castoriadis's work represents a vigorous reproach to all declarations that history ends in the nihilistic imaginary of limitless production, exploitation and consumption that animates global capitalism. 


\section{References}

Ablett, P. and Morley, C. (2020) 'Social work education as democratic paideia? Insights from Castoriadis', In C. Morley, P. Ablett, C. Nobel and S. Cowden (eds), The Routledge handbook of critical pedagogies for social work, Abingdon, Oxon: Routledge.

Ablett, P., Morley, C. and Newcomb, M. (2019) Social work, human services and basic income, In E. Klein, J. Mays and T. Dunlop (eds), Implementing a basic income in Australia: Pathways forward, London. Palgrave Macmillan, pp. 215-36.

Agora International (2014) About Cornelius Castoriadis, http://agorainternational.org/about.html (Accessed: December 23, 2018).

Allan, J., Briskman, L. and Pease, B.(eds) (2009) Critical social work: Theories and practices for a socially just world (2nd edn), Crows Nest, NSW: Allen \& Unwin.

Althusser, L. (1971) Lenin and philosophy and other essays, New York, NY: Monthly Review Press.

Arnd-Caddigan, M. and Pozzuto, R.(2006) Truth in our time, Qualitative Social Work, 5(4): 423-40. doi: 10.1177/1473325006070285

Aymer, C. and Okitikpi, T. (2000) Epistemology, ontology and methodology: what's that got to do with social work? Social Work Education, 19(1): 67-75. doi: 10.1080/026154700114667

Barthes, R. (1977) The death of the author, In R. Barthes, Image-music-text (trans S. Heath), New York, NY: Hill and Wang.

Bell, K. (2012) Towards a post-conventional philosophical base for social work, The British Journal of Social Work, 42(3): 408-23. doi: 10.1093/bjsw/bcr073

Biestek, F. (1951) The principle of client self-determination, Social Casework, 32(9): 369-75. doi: 10.1177/104438945103200902

Borden,W. (2010) Taking multiplicity seriously: pluralism, pragmatism and integrative perspectives in clinical social work, In W. Borden (ed), Reshaping theory in contemporary social work: Toward a critical 
pluralism in clinical practice, New York, NY: Columbia University Press, pp. 3-27.

Breckman, W. (1998) Cornelius Castoriadis contra postmodernism: beyond the 'French Ideology', French Politics and Society, 16(2): 30-42.

Bryant, L. (ed) (2015) Critical and creative research methodologies in social work, Surrey: Ashgate.

Castoriadis, C. (1984) Crossroads in the labyrinth (trans K. Soper and M. Ryle), Cambridge: MIT Press.

Castoriadis, C.(1987) The imaginary institution of society (trans K. Blamey), Cambridge: Polity.

Castoriadis, C. (1990a) Individual, society, rationality, history, Thesis Eleven, 25(1): 59-90. doi: 10.1177/072551369002500105

Castoriadis, C. (1990b) Does the idea of revolution still make sense?, Thesis Eleven, 26(1): 123-38. doi: 10.1177/072551369002600109

Castoriadis, C. (1991) Philosophy, politics, autonomy: Essays in political philosophy (ed D.A. Curtis), Oxford: Oxford University Press.

Castoriadis, C. (1992) The retreat from autonomy: post-modernism as generalized conformism, Thesis Eleven, 31(1): 14-23. doi: $10.1177 / 072551369203100103$

Castoriadis, C. (1997a) World in fragments. Writings on politics, society, psychoanalysis, and the imagination (ed and trans D.A. Curtis), Stanford, CA: Stanford University Press.

Castoriadis, C. (1997b) The Castoriadis reader (ed and trans D.A. Curtis), Oxford: Blackwell Publishers.

Castoriadis, C.(2007) Figures of the thinkable (trans H.Arnold), Stanford, CA: Stanford University Press.

Cohn-Bendit, D. and Cohn-Bendit, G. (1968) Obsolete communism: The left-wing alternative (trans A. Pomerans), New York, NY: McGraw-Hill.

Curtis, D.A. (1992) Cornelius Castoriadis, In P. Beilharz (ed), Social theory: A guide to central thinkers, Sydney: Allen and Unwin.

Ferguson, I. (2008) Reclaiming social work: Challenging neoliberalism and promoting social justice, London: Sage. 
Ferguson, I. (2013) Social workers as agents of change, In S.Webb and M.

Gray (eds), The new politics of social work, Basingstoke: Palgrave Macmillan.

Ferguson, I. (2016) The new social work radicalism: results and prospects, Social Alternatives, 35(4): 90-5.

Ferguson, I. and Lavalette, M. (1999) Social work, postmodernism and Marxism, European Journal of Social Work, 2(1): 27-40. doi: $10.1080 / 13691459908413803$

Fook, J. (2016) Social work: A critical approach to practice (3rd edn), London: Sage.

Foucault, M. (1981[1970]) The order of discourse, In R.Young (ed), Untying the text: A poststructuralist reader, Boston, MA: Routledge and Kegan.

Garrett, P. (2015) Active equality: Jacques Ranciere's contribution to social work's 'New Left', British Journal of Social Work, 45(4): 1207-23. doi: $10.1093 / \mathrm{bjsw} / \mathrm{bct} 188$

Garrett, P. (2018) Social work and social theory: Making connections (2nd edn), Bristol: Policy Press.

Gray, M. and Webb, S. (2009) The return of the political in social work, International Journal of Social Welfare, 17(2): 111-15. doi: 10.1111/j.1468-2397.2008.00626.x

Gray, M. and Webb, S. (2013) The new politics of social work, Houndmills: Palgrave Macmillan.

Hastings-King, S. (1999) L'Internationale situationniste, Socialisme ou Barbarie, and the crisis of the Marxist imaginary, SubStance, 28(3): 2654. doi: $10.1353 /$ sub.2006.0007

Healy, K. (2000) Social work practices: contemporary perspectives on change, London: Sage.

Honneth,A.(1986) Rescuing the revolution with an ontology:on Cornelius Castoriadis' theory of society, Thesis Eleven, 14: 62-78. doi: $10.1177 / 072551368601400106$

IFSW (International Federation of Social Workers) (2014) Global definition of social work, www.ifsw.org/what-is-social-work/global-definition-of- 
social-work/

James, C.L.R., Lee, G. and Castoriadis, C. (2005[1958]) Facing reality: The

New society: Where to look for it and how to bring it closer, Chicago, IL:

Charles H. Kerr Publishing Company.

Joas, H. (1989) Review essay: institutionalization as a creative process: the sociological importance of Cornelius Castoriadis' political philosophy, American Journal of Sociology, 94(5): 1184-99. doi: 10.1086/229115

Kennelly, C.(2017) Universal basic income guarantee: the next 'BIG'thing in Canadian Social Policy, Canadian Association of Social Workers (CASW), www.casw-acts. ca/sites/caswacts.ca/files/attachements/universal_basic_income_guarantee_the_next_big_thing_in_canadian_social_policy_0.pdf

Lavalette, M. (ed) (2011) Radical social work today: Social work at the crossroads, Bristol: Policy Press.

Leonard, P. (1997) Postmodern welfare: Reconstructing an emancipatory project, London: Sage.

Lyotard, F. (1993) The postmodern condition :A report on knowledge, (trans G. Bennington and B. Massumi), Minneapolis, MN: University of Minnesota Press.

Madhu, P. (2005) Towards a praxis model of social work: a reflexive account of 'praxis intervention' with the Adivasis of Attappady, unpublished PhD thesis, Mahatma Gandhi University, India.

McDermott, F. (ed) (1975) Self-determination in social work: A collection of essays on self-determination and related concepts by philosophers and social work theorists, London: Routledge and Kegan Paul.

Memos, C. (2014) Castoriadis and critical theory: Crisis, critique and radical alternatives, Basingstoke: Palgrave MacMillan.

Metcalfe, A. (1989) The importance of freedom and dignity, Anthropological Forum, 1(1): 49-68. doi: 10.1080/00664677.1989.9967395

Moreau, M. (1979) A structural approach to social work practice, Canadian Journal of Social Work Education, 5(1): 78-94.

Morley, C. and Macfarlane, S.(2012)The nexus between feminism and 
postmodernism: still a central concern for critical social work, British Journal of Social Work, 42(4): 687-705. doi: 10.1093/bjsw/bcr107

Morley, C., Ablett, P. and Macfarlane, S. (2019) Engaging with social work: A critical introduction (2nd edn), South Melbourne: Cambridge.

Mullaly, B. (2007) The new structural social work (3rd edn), Ontario: Oxford.

Nguyen, T.O. (2002) Historical development and characteristics of social work in today's Vietnam, International Journal of Social Welfare, 11(1): 84-91. doi: 10.1111/1468-2397.00199

Ojeili, C. (2001) Post-Marxism with substance: Castoriadis and the autonomy project, New Political Science, 23(2): 225-39. doi: $10.1080 / 07393140120054047$

Parton, N. and O'Byrne, P. (2000) Constructive social work: towards a new practice, Basingstoke: Palgrave.

Pease, B. and Fook, J. (eds) (1999) Transforming social work practice: Postmodern critical perspectives, Leonards, NSW: Allen and Unwin. Pease, B., Goldingay, S., Hosken, N. and Nipperess, S. (eds) (2016) Doing critical social work: Transformative practices for social justice, Crows Nest, NSW: Allen \& Unwin.

Peile, C. (1993) Determinism versus creativity: which way for social work, Social Work, 38(2): 127-34.

Peregalli,A. (2002) Contro venti e maree. La seconda guerra mondiale e gli Internazionalisti del 'Terzo Fronte', Grecia: Aghis Stinas e l'Unione Comunista Internazionalista, http:// libcom.org/library/peregalli-stinasarturo-peregalli

Pritchard, C. and Taylor, R.(1978) Social work: Reform or revolution?, London: Routledge and Kegan Paul.

Shuttleworth, R. (1992) The imaginary institution of a geropsychiatric rehabilitation program. The social construction of symptom, cause and cure, paper presented at the 91st Annual Meeting of the American Anthropological Association, San Francisco, CA, December.

Shuttleworth, R. (2013) Conceptualising disabled sexual subjectivity, In M. 
Pallotta- Chiarolli and B. Pease (eds), The politics of recognition and social justice: Transforming subjectivities and new forms of resistance, London: Routledge.

Singer, B. (1979) The early Castoriadis: socialism, barbarism and the bureaucratic thread, Canadian Journal of Political and Social Theory, 3(3): 35-56.

Skinner, B. (1971) Beyond freedom and dignity, Indianapolis, IN: Hackett Publishing.

Souza, M, De.(2000) Urban development on the basis of autonomy: a politico philosophical and ethical framework for urban planning and management, Philosophy \& Geography, 3(2): 187-201, doi: 10.1080/13668790008573712.

Strega, S. and Brown, L. (2015) Research and resistance: Revisiting critical, indigenous and anti-oppressive approaches (2nd edn), Toronto: Canadian Scholars Press and Women's Press.

Webb, S. (2001) Some considerations on the validity of evidence based practice in social work, British Journal of Social Work, 31(1): 57-79. doi: $10.1093 / \mathrm{bjsw} / 31.1 .57$

Yu, N. (2006) Interrogating social work: Philippine social work and human rights under martial law, International Journal of Social Welfare, 15(3): 257-63. doi: 10.1111/j.1468-2397.2006.00401.x

Zimmerman, J. (1989) Determinism, science and social work, Social Service Review, 63(1): 52-62. doi: 10.1086/603678 